\title{
REGULIARIŲ SPORTINIŲ ŽAIDIMŲ IR CIKLINIŲ SPORTO ŠAKŲ PRATIMŲ POVEIKIS 11-14 METŲ BERNIUKŲ RAUMENŲ BEI ŠIRDIES IR KRAUJAGYSLIŲ SISTEMOMS
}

\author{
Arūnas Emeljanovas, Eurelija Venskaitytė, Laura Danusevičiūtė, Jonas Poderys \\ Lietuvos kūno kultūros akademija, Kaunas, Lietuva
}

Arūnas Emeljanovas. Lietuvos kūno kultūros akademijos Lengvosios atletikos katedros doktorantas. Moksliniu tyrimų kryptis — sportuojančių vaikų parengtumo, funkcinès būklès ir treniruotès vyksmo kompleksinis vertinimas.

\section{SANTRAUKA}

Vaiko fizinis išsivystymas yra endogeniniu ir egzogeniniu veiksniu sqveikos rezultatas. Širdies ir kraujagysliu sistemos (ŠKS) funkcinès galimybès dažnai tampa veiksniu, ribojančiu organizmo adaptacines galimybes, dèl to ŠKS adaptacija prie fiziniu krūviu yra viena iš reikšmingu salygu, lemianči bendrq organizmo prisitaikyma prie aplinkos sqlygu.

Tyrimo tikslas - nustatyti 11-14 m. berniuku raumenu funkcijos bei širdies ir kraujagysliu sistemos adaptacijos prie reguliariu ilgalaikiu sportiniu žaidimu ir cikliniu sporto šaku pratimu ypatumus. Panaudojant kompinterine programa „Kaunas—Krūvis“, buvo registruojama 12 standartiniu elektrokardiogramos (EKG) derivaciju. Santykinis raumenu galingumas ir šuoliu aukštis matuojamas tiriamajam atliekant 30 s vertikalaus šuoliavimo testa (atsistojus ant kontaktinès platformos).

Tyrimo duomenys patvirtino daugelio kitu autoriu teiginius, kad reguliarūs fiziniai krūviai teigiamai veikia $11-14 \mathrm{~m}$. berniuku šuoliu aukščio ir 11-13 m. berniuku santykinio raumenu galingumo rodiklius - blogiausi buvo nesportuojančiu vaiku. Žaidejai pranašiausi vertinant daugeli širdies ir kraujagysliu sistemos rodikliu. Viso tyrimo metu ju. širdies susitraukimu dažnis buvo mažesnis už cikliniu šaku sportininku ir nesportuojančiu vaiku (ypač tai pasireiškẻ $13 \mathrm{~m}$. amžiaus tarpsniu). $13 \mathrm{~m}$. amžiaus grupès tiriamuju elektrokardiogramos JT intervalo reikšmés po fiziniu krūviu statistiškai patikimai $(p<0,05)$ skyrèsi tarp žaidèju ir cikliniu šaku sportininku bei nesportuojančiu vaiku. Lyginant $14 \mathrm{~m}$. amžiaus grupes, buvo aptiktas mažesnis ŠKS rodikliu skirtumas tarp grupiu. Apibendrinant šio tyrimo rezultatus galima teigti, kad išoriniu ir vidiniu veiksniu sqveika lemia 11-14 m. berniuku tiek raumenu, tiek širdies ir kraujagysliu sistemu funkciniu galimybiu lavejimq ir ju poreiškio ypatumus fiziniu krüviu metu. Kintamo intensyvumo fizinis krūvis, büdingas sportiniu žaidimu pratyboms, yra reikšmingas išorinis veiksnys, lemiantis greitesnę širdies ir kraujagysliu sistemos funkciniu rodikliu kaita 13 m. amžiaus tarpsniu. Tačiau endogeniniai veiksniai, ypač 13-14 m. amžiaus tarpsniu, labai stipriai paveikia širdies ir kraujagysliu sistema, dèl to net nesportuojančiu vaiku. ŠKS funkciniai rodikliai sparčiai gerèja.

Raktažodžiai: adaptacija, amžiaus tarpsniai, širdies ir kraujagysliu sistema.

\section{IVADAS}

$\mathrm{V}$ aikų ir jaunuolių amžiaus tarpsniu suintensyveja augimo ir vystymosi procesai, nusistovi tam tikri ryšiai tarp atskiru organizmo funkcinių sistemų. Vaiko fizinis išsivystymas yra endogeninių ir egzogeniniu veiksniu sąveikos rezultatas (Rowell, 1993; Mokrane, Nadeau, 1998; Naužemys ir kt., 2000; Winsley et al., 2003). Paauglių fiziologinių funkcijų vystymosi mechanizmas yra sudètinis: tuo metu padideja ląstelių skaičius, jų dydis, o ląstelių funkcijų pasiskirstymas gali lemti fiziologinių reakcijų i fizini krūvị pokyti (Gilbert, 2000; Lodish et al., 2000). Širdies ir kraujagyslių sistemos (ŠKS) funkcinès galimybės dažnai yra veiksnys, ribojantis organizmo adaptacines galimybes, dèl to ŠKS adaptacija prie fizinių krūvių yra viena iš reikšmingų sąlygų, lemiančiu bendrą organizmo prisitaikymą prie aplinkos (Hainsworth, 1995; Fletcher et al., 1996; Ivaniura, 1999; Winsley et al., 2003; Poderys ir kt., 2004).

Mokslinėse publikacijose pateiktų daugelio jaunujų sportininkų ir nesportuojančiujų rodiklių palyginimas rodo ne tik neginčijamai teigiamą treniruotes (Strong et al., 2005), bet ir atrankos proceso (Платонов, 2004) poveiki. Tyrimų rezultatai byloja, kad prieš lytinį brendimą varžybinis 
sportas augimo neigiamai neveikia, o kūno konstitucijos veiksniai yra svarbūs vaikams renkantis sporto šaką (Wilmore, Costill, 1999; Damsgaard et al., 2000; Armstrong, Welsman, 2005). Todèl šio tyrimo metu palyginome $11-14 \mathrm{~m}$. amžiaus berniukų vystymosi ypatumus, vertindami raumenų bei ŠKS adaptacijos ypatybes, atsižvelgdami i jų sporto šaką. Tyrimo tikslas - nustatyti 11-14 m. berniukų, raumenų vystymosi bei ŠKS adaptacijos prie reguliarių ilgalaikių sportinių žaidimų ir ciklinių sporto šakų pratimų ypatumus.

\section{TYRIMO METODIKA}

Tyrimai atlikti LKKA Kineziologijos laboratorijoje 2002-2006 metais. Buvo tiriami 257 sąlygiškai sveiki, neturintys žalingų ipročių 11-14 m. berniukai. Tiriamieji - vaikai, lankantys Kauno miesto vidurines ir ivairias sporto mokyklas, buvo suskirstyti $\mathfrak{i}$ tris grupes: nesportuojantieji N 11-14 $(\mathrm{n}=85)$, kultivuojantys ciklines sporto šakas — lengvaatlečiai bėgikai C $11-14(\mathrm{n}=89)$ ir žaidejjai — krepšininkai, rankininkai, futbolininkai S $11-14(\mathrm{n}=83)$.

Tiriamuju organizmo funkcinès būklès ir adaptacijos ypatybėms vertinti naudota kompiuterinè EKG registravimo ir analizès įranga „KaunasKrūvis“. Buvo registruojama 12 standartinių EKG atvadu, matuojamas arterinis kraujo spaudimas (AKS). Analizuojant gautus rezultatus buvo vertinami šie ŠKS funkciniai rodikliai: širdies susitraukimų dažnis (ŠSD), JT intervalas, intervalų JT / RR santykis, ST segmento depresija. Tiriamieji po pradinio rodiklių registravimo atliko Ruf-
1 pav. ŠSD kaita atliekant Rufjè fizinio krūvio mèginį ir $30 \mathrm{~s}$ vertikalaus šuoliavimo testą
Pastaba. a - skirtumas tarp nesportuojančiujuc ir žaideju, b - tarp nesportuojančiujų ir ciklinių šakų sportininkų, c - tarp žaidejjų ir ciklinių šakų sportininkų — statistiškai patikimas skirtumas $(\mathrm{p}<0,05)$.

1 EKG - prieš krūvị; 4-14 EKG — atsigavimas po Rufjè mėginio; $15-25$ EKG — atsigavimas po $30 \mathrm{~s}$ vertikalaus šuoliavimo testo.

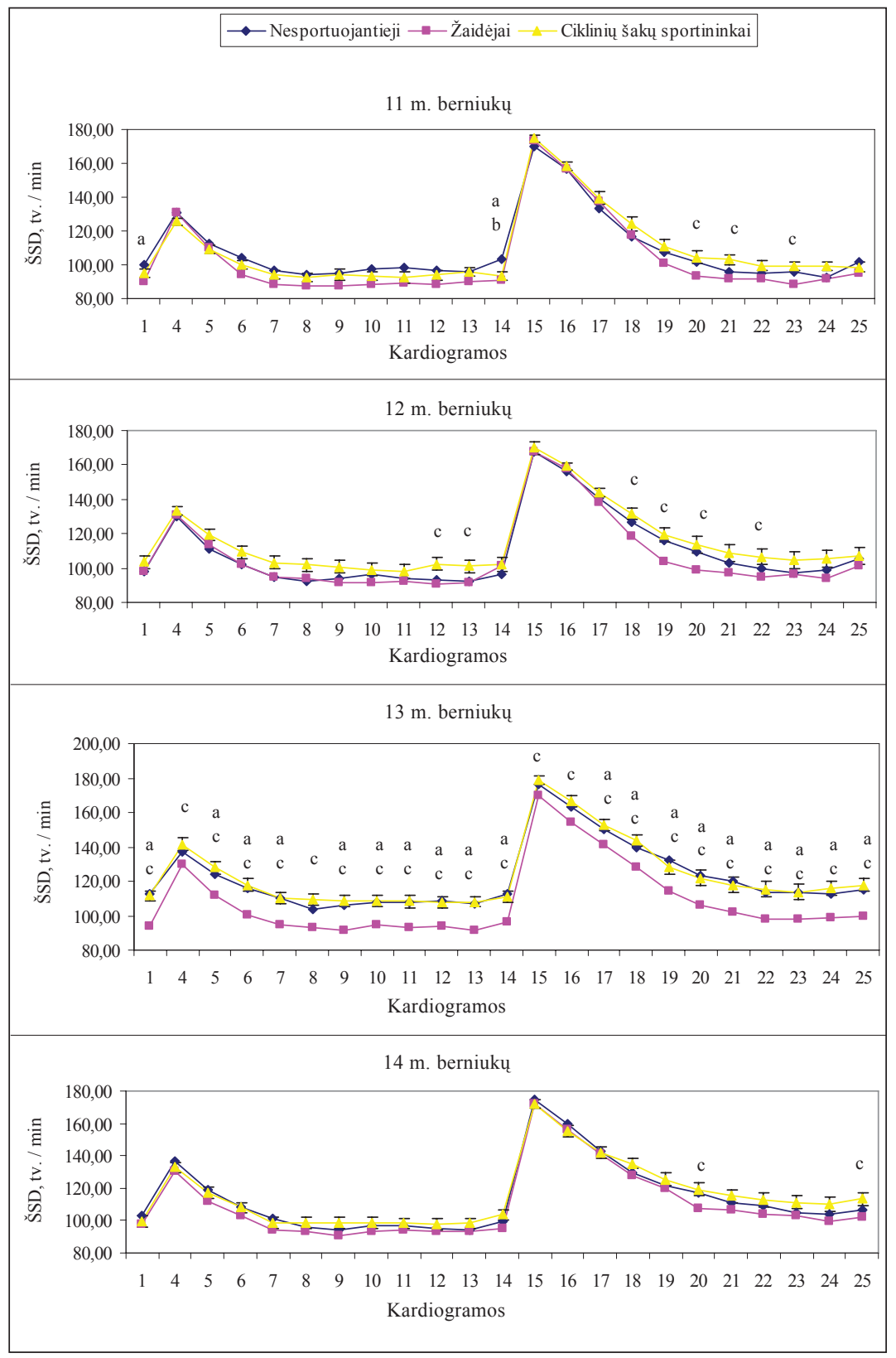


jẻ fizinio krūvio mėgini ( 30 pritūpimų per $45 \mathrm{~s}$ ). Paskui tiriamieji atliko maksimaliu pastangu $30 \mathrm{~s}$ vertikalaus šuoliavimo testą, kurio metu buvo registruojama kiekvieno šuolio aukštis ir santykinis raumenu galingumas $(\mathrm{W} / \mathrm{kg})$.

Vertinant tyrimo rezultatus buvo skaičiuojami registruotų rodiklių aritmetiniai vidurkiai $(\bar{x})$ ir jų paklaidos $(\mathrm{S} \overline{\mathrm{x}})$, apskaičiuojamas skirtumo patikimumas naudojant dvipusi Stjudento $t$ kriteriju, taikomą priklausomoms ir nepriklausomoms imtims. Patikimas skirtumas tarp lyginamujų dydžių laikytas tada, kai paklaida neviršydavo $5 \%$, t. y. p $<0,05$.

\section{REZULTATAI}

11-14 m. nesportuojančių vaikų, sportinių žaidimų ir ciklinių šakų sportininkų AKS rodiklių palyginimas neatskleidè statistiškai patikimo skirtumo tarp AKS rodiklių, registruojamų ramybès sąlygomis bei joms keičiantis, kai buvo atliekami abu fizinio krūvio testai. Todèl negalime teigti, kad tiek sportinių žaidimų, tiek ciklinių sporto šakų reguliarios fizinès pratybos reikšmingai veikia $11-14 \mathrm{~m}$. berniukų AKS rodiklių kaitą.

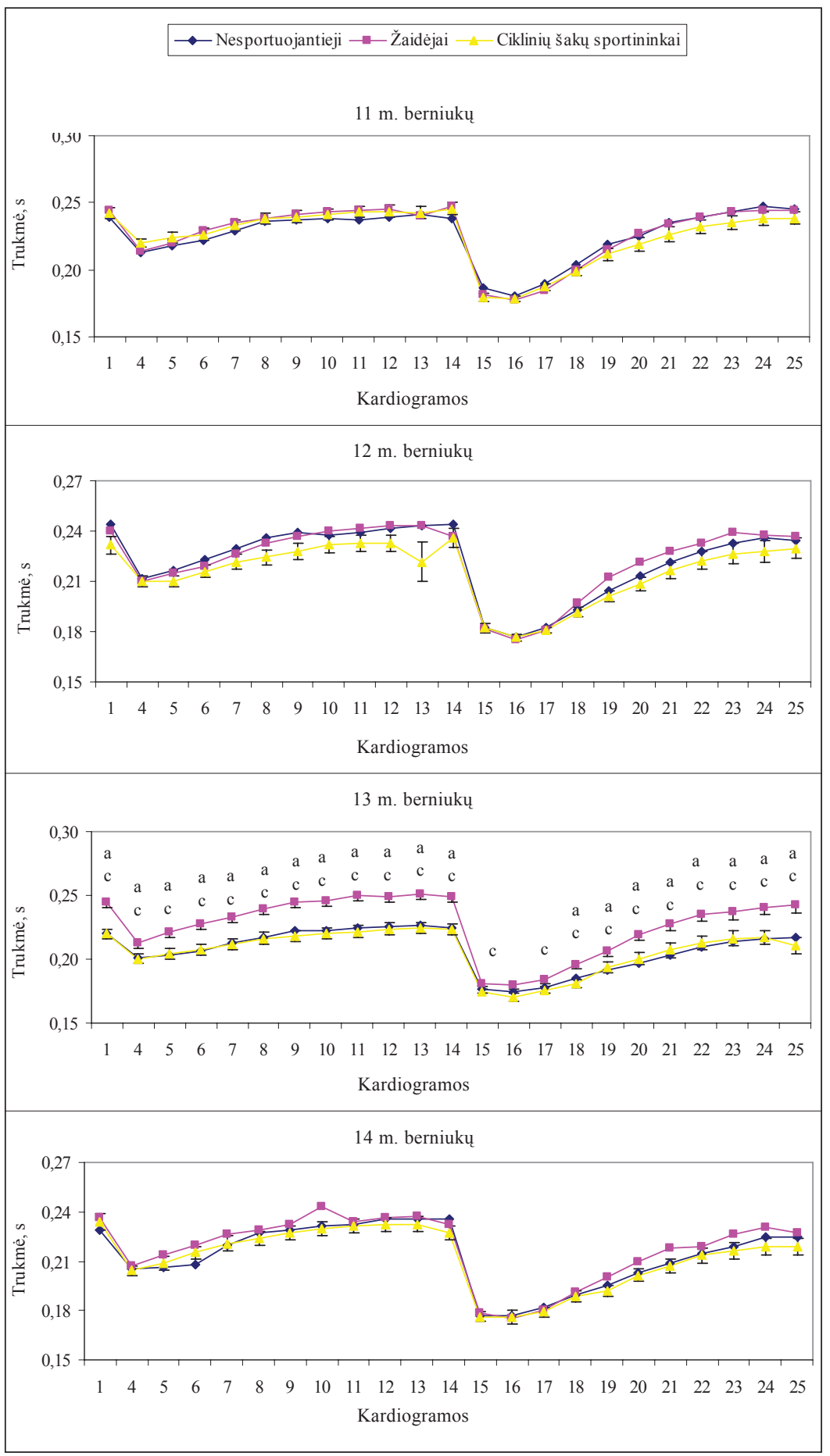

2 pav. Elektrokardiogramos JT intervalo kaita atliekant Rufjè fizinio krūvio mèginị ir $30 \mathrm{~s}$ vertikalaus šuoliavimo testą

Pastaba. a - skirtumas tarp nesportuojančiųjų ir žaidejjų, c - tarp žaidejų ir ciklinių šakų sportininkų - statistiškai patikimas skirtumas $(\mathrm{p}<0,05)$.

1 EKG - prieš krūvị; 4-14 EKG - atsigavimas po Rufjè mėginio; 15-25 EKG — atsigavimas po $30 \mathrm{~s}$ vertikalaus šuoliavimo testo. 
3 pav. 30 s vertikalaus šuoliavimo testo šuolių aukščio rezultatai
Pastaba. a - skirtumas tarp nesportuojančiuju ir žaidejuc, b - nesportuojančiujuc ir ciklinių šaku sportininku, c - tarp žaidejju ir cikliniu šaku sportininku — statistiškai patikimas skirtumas $(\mathrm{p}<0,05)$.

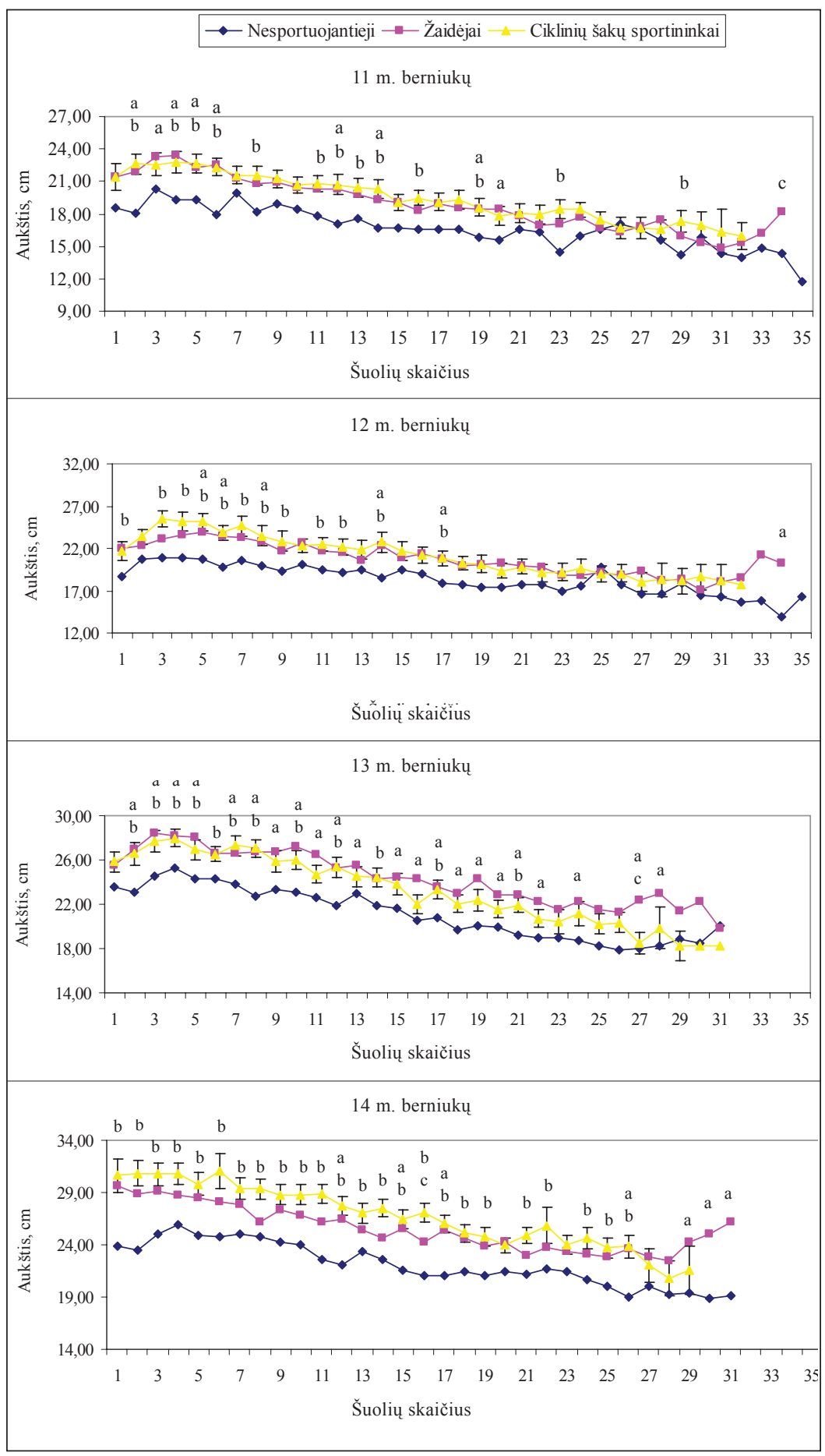

Vertindami ŠSD kaitą aptikome, kad žaidimų pratybas lankančių vaikų ŠSD reikšmès mažiausios (1 pav.), ir tai būdinga visų amžiaus grupių tiriamiesiems, o $13 \mathrm{~m}$. amžiaus tarpsniu skirtumas tarp grupių rodiklių buvo statistiškai patikimas $(\mathrm{p}<0,05)$.

2 paveiksle pateikta elektrokardiogramos JT intevalo kaita atliekant du fizinio krūvio testus. Aptikome, kad 11 ir $12 \mathrm{~m}$. amžiaus tarpsniu nebuvo statistiškai reikšmingo skirtumo $(\mathrm{p}>0,05)$, kai tuo tarpu $13 \mathrm{~m}$. amžiaus grupès JT inervalo reikšmės jau statistiškai patikimai $(\mathrm{p}<0,05)$ skyrèsi tarp žaidèjų ir ciklinių šakų sportininkų bei nesportuojančių vaikų.

Atliekant Rufjè fizinio krūvio mègini ir $30 \mathrm{~s}$ vertikalaus šuoliavimo testą nebuvo užregistruota statistiškai patikimo skirtumo tarp grupių, lyginant elektrokardiogramos intervalu JT ir RR santykio (JT / RR) kaita. Tokia pati tendencija nustatyta ir vertinant ir ST segmento depresijos kaita.

Raumenų darbingumo rodikliai (šuolių aukštis, santykinis raumenų galingumas ir jų kaita yra 


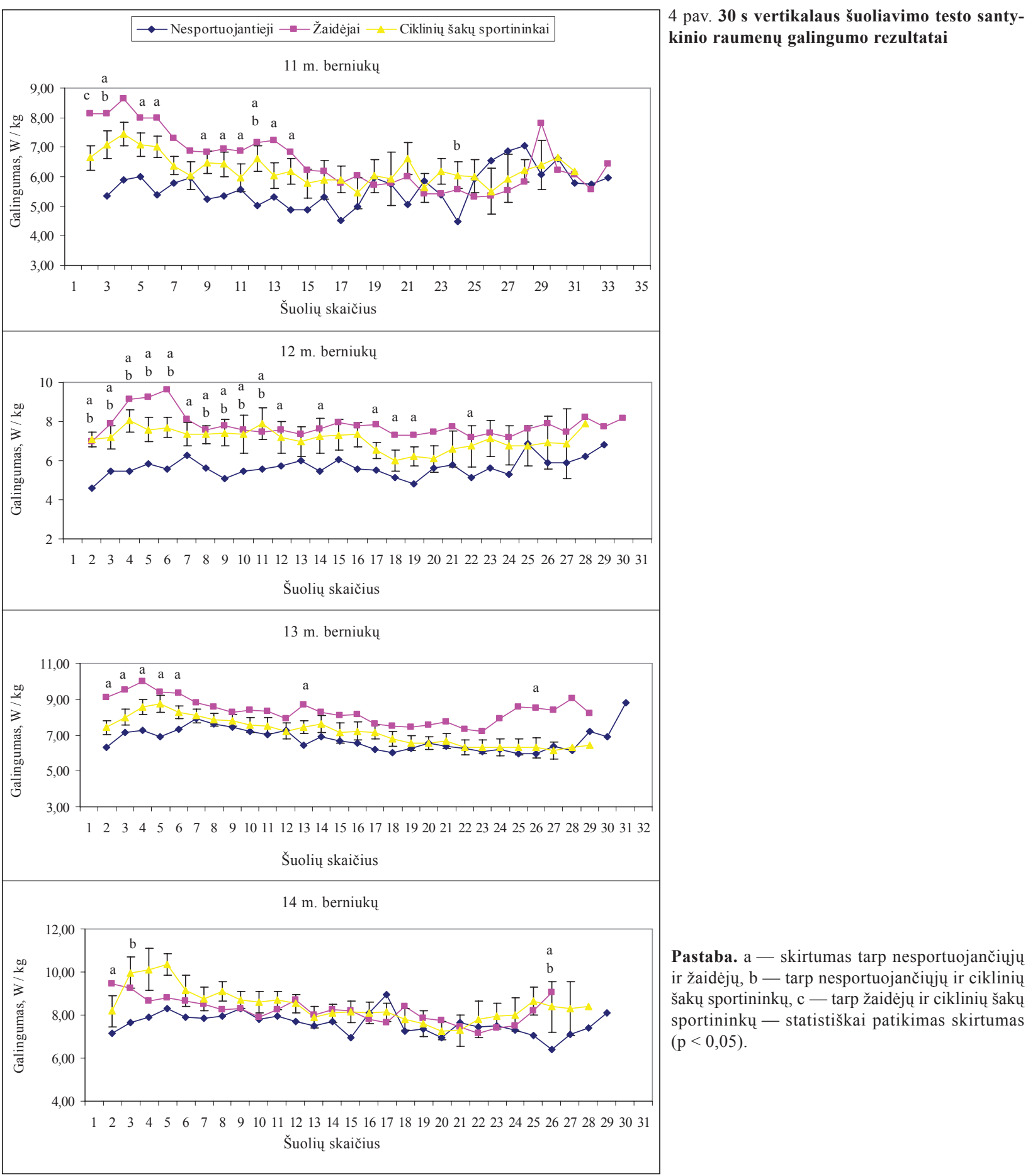

pateikta 3 ir 4 paveiksle. Visų tirtų amžiaus grupių nesportuojantys vaikai tiek testo pradžioje, tiek viso testo metu (per $30 \mathrm{~s}$ ) i aukšti pašoko mažiau nei žaidejjai ar ciklinių šaku sportininkai (skirtumas statistiškai patikimas, $p>0,05)$. Žaidèjų ir ciklinių šakų sportininkų rezultatai buvo panašūs, todèl statistiškai reikšmingai nesiskyrè.

Vertindami raumenu galingumo rodiklius nustatėme, kad $11-13 \mathrm{~m}$. berniuku santykinis raumenų galingumas didžiausias žaidẻjų, mažiausas - nesportuojančių vaikų ir statistiškai patiki- mai $(\mathrm{p}<0,05)$ skyrèsi tarp šiu grupių tik testo pradžioje. Skirtingai nuo kitų amžiaus grupių, $14 \mathrm{~m}$. berniukų šuoliu galingumas per $30 \mathrm{~s}$ statistiškai reikšmingai nesiskyrè (4 pav.).

\section{REZULTATŲ APTARIMAS}

Organizmo augimo ir vystymosi ypatybes lemia vidiniai veiksniai, tačiau reikšmingos ittakos tam turi ir išoriniai. Fiziniai krūviai yra priskiriami išorinių veiksnių grupei. Šiuo tyrimu ieškojo- 
me atsakymo ị klausimus: kaip reguliarūs fiziniai krūviai gali paveikti vaiko funkcinio parengtumo kaitą ir koks yra fizinio krūvio poveikis; kuris iš krūviu (ciklinis ar kintamo intensyvumo) stipriau paveikia ŠKS ir raumenu ypatybes.

EKG ir AKS rodikliai, užregistruoti atliekant dozuoto ar maksimalaus krūvio testus, yra taikomi funkcinei būklei nustatyti. Jie leidžia ivertinti greitosios ir ilgalaikès adaptacijos ypatybes. AKS pokyčiai yra susiję su padidejjusiu širdies minutiniu tūriu ir periferinių kraujagysliu pasipriešinimo pokyčiais (Vainoras, 1996; Saltin et al., 1998; Pollock et al., 2000). Šio tyrimo rezultatai vertinant AKS kaitą parodé, kad fizinių krūvių poveikis AKS reakcijai yra tik nestipriai išreikštas, tačiau skirtumas tarp tirtu grupių nebuvo statistiškai reikšmingas. Tokie tyrimo rezultatai gali būti paaiškinami: šio amžiaus tarpsnio vaikams taikomi optimalūs fiziniai krūviai daugiau lemia raumenų ypatybių lavejjimą ir kiek mažiau - ŠKS. Tai būtų lyg ir netiesiogiai patvirtinama, kad vaikų treneriai parinkdavo optimalią treniravimo strategiją, tačiau tiksliu irodymų neturime.

Dèl skirtingos miokardo fiziologinès reakcijos i neurotransmiterius (acetilcholiną ir noradrenalina), veikiant parasimpatinei ir simpatinei nervų sistemoms, vaikų ir paauglių ŠSD kaita didesnè (Rowell, 1993; Hainsworth, 1995; Žemaityte, 1997; Mokrane, Nadeau, 1998; Winsley et al., 2003). Vertinant ŠSD, registruotą viso tyrimo metu, aptikome, kad mažiausios jo reikšmès pastebimos tarp žaidejju — statistiškai patikimos buvo tik po anaerobinio fizinio krūvio (30 s vertikalaus šuoliavimo testo). Lyginant gautus duomenis amžiaus aspektu, mažiausios ŠSD reikšmès buvo $13 \mathrm{~m}$. žaidejų grupeje ir reikšmingai skyrèsi nuo nesportuojančiuju ir ciklinių šakų sportininkų. Mažesnès ŠSD reikšmès rodo, kad sportinių žaidimų treniruotes lankančių berniuku širdis susitraukinejja lèčiau, t. y. ilgiau trunka diastolè (širdies atsipalaidavimas) ir greitesnè ŠKS mobilizacija krūvio pradžioje. Visgi šios jų funkcijos kiek lèčiau atsigauna po fizinių krūvių nei ciklinių šakų sportininkų. Tai liudija, kad fizinių krūvių specifiškumas turi įtakos ŠKKS adaptacijos ypatybėms.

Elektrokardiogramos JT intervalas gali būti naudojamas kaip skilvelių repoliarizacijos trukmès rodiklis (Hlaing et al., 2005), o jo kaita yra glaudžiai susijusi su metabolizmo pokyčiais miokarde (Vainoras, 1996; Vainoras ir kt., 2000).
Skirtingų sporto šakų berniukų JT intervalo kaita buvo analogiška ir statistiškai patikimo skirtumo tarp grupių nebuvo nustatyta. Todèl remiantis šio tyrimo rezultatais galima teigti, kad fizinių krūvių poveikis miokardo metabolizmo ypatumams nèra greitas ir pasireiškia per trumpą treniravimosi laikotarpi. Tačiau $13 \mathrm{~m}$. amžiaus grupès tiriamuju elektrokardiogramos JT intervalo reikšmès po fizinių krūvių statistiškai patikimai $(\mathrm{p}<0,05)$ skyrèsi tarp žaidèjų, ciklinių šakų sportininkų ir nesportuojančiu vaikų.

Elektrokardiogramos JT ir RR intervalų santykis JT / RR yra vienas iš ŠKS funkcijos mobilizacijos rodiklių fizinio krūvio metu (Poderys ir kt., 2006). Atliekant Rufjè mėgini ir 30 s vertikalaus šuoliavimo testą, nebuvo užregistruotas elektrokardiogramos JT / RR intervalų santykio reikšmingas skirtumas tarp tiriamuju grupių. Tokia pati tendencija pastebima vertinant ir ST segmento amplitudę. Šio tyrimo rezultatai tik liudijo apie amžinius pokyčius, tačiau reikšmingo fiziniu krūviu poveikio šio rodiklio kaitai neparodè.

Raumenu darbingumo vertinimo duomenys patvirtino daugelio kitu autoriu teiginius, kad fiziniai pratimai turi itakos augimo ir vystymosi procesams (Rowell, 1993; Wilmore, Costill, 1999). Sportinių žaidimu pratybose daugiau taikomi įvairūs šuoliavimo pratimai, o to nedaro ciklinių šakų sportininkai, todèl jų santykinio raumenų galingumo reikšmès didesnès, ir tai yra krūvių specifiškumo pasekmè.

\section{IŠVADOS}

Apibendrinant tyrimo rezultatus galima teigti, kad išorinių ir vidinių veiksnių sąveika lemia $11-14 \mathrm{~m}$. berniuku tiek raumenu, tiek širdies ir kraujagyslių sistemų funkcinių galimybių lavejjimą ir jų poreiškio fizinių krūvių metu ypatumus. Kintamo intensyvumo fizinis krūvis, būdingas sportinių žaidimų pratyboms, yra reikšmingas išorinis veiksnys, lemiantis greitesnę širdies ir kraujagyslių sistemos funkcinių rodiklių kaitą $13 \mathrm{~m}$. amžiaus tarpsniu, o endogeniniai veiksniai, ypač $13-14 \mathrm{~m}$. amžiaus tarpsniu, labai stipriai veikia širdies ir kraujagysliu sistema, dèl to net nesportuojančių vaikų ŠKS funkciniai rodikliai sparčiai gerèja. 


\title{
LITERATŪRA
}

Amstrong, N., Welsman, J. (2005). Physiology of the child athlete. Exter: Children's Health and Exercise Research Centre.

Damsgaard, R., Bencke, J., Mathiesas, G. (2000). Is prepubertal growth adversely affected by sport? Medicine and Science in Sports and Exercises, Vol. 32, 10, $1698-1703$.

Fletcher, G. F., Balady, G., Blair, S. N. et al. (1996). Recommendations for physical activity programs for all Americans: a statement for health professionals by the Committee on Exercise and Cardiac Rehabilitation of the Council on Clinical Cardiology, American Heart Association. Circulation, 94, 857-862.

Gilbert, S. F. (2000). Developmental Biology (6th ed.). Massachusetts: Sinauer Associates. P. 1437.

Hainsworth, R. (1995). The control and physiological importance of heart rate. M. Malik, A. J. Camm (Eds.), Heart rate variability. New York. P. 3-19.

Hlaing, T., Dimino, T., Kowey, P. R., Yan, G. X. (2005). ECG Repolarization Waves: Their Genesis and Clinical Implications. Ann Noninvasive Electrocardiol, 10 (2), $211-23$.

Ivaniura, I. O. (1999). The effect of prolonged physical loads on the cardiovascular system of middle-school-aged pupils. Fiziol Zh, 45 (6), 67-74.

Lodish, H., Berk, A., Zipursky, S. L. et al. (2000). Molecular Cell Biology. New York. P. 1084.

Mokrane, A., Nadeau, R. (1998). Dynamics of heart rate response to sympathetic nerve stimulation. American Journal of Physiology, 275, H 995-1001.

Naužemys, R., Saplinskas J., Kniukšta R. (2000). Fizinio aktyvumo paslaptys. Vilnius.

Olson, D. (1996). What is training? Current Biology, 1, 6 (12), 1539.

Poderys, J., Buliuolis, A., Trinkūnas, E., Grūnovas, A. (2004). Intensyvių sekinančių anaerobinių krūvių itaka arterinio kraujo spaudimo rodikliams. Ugdymas. Küno kultūra. Sportas, 1 (51), 19-24.

Poderys, J., Venskaitytė, E., Poderytė, K., Ežerskis, M.
(2006). Dvikovos sporto šakų atstovų atsigavimo proceso ypatybės ir jų kaita po didelès apimties koncentruotų jëgos greitumo krūvių. Sporto mokslas, 1 (43), 48-53.

Pollock, M. L., Franklin, B. A., Balady, G. J. (2000). Resistance exercise in individuals with and without cardiovascular disease: Benefits, rationale, safety, and prescription: An advisory from the Committee on Exercise, Rehabilitation, and Prevention, Council on Clinical Cardiology, American Heart Association. Circulation, 101,828

Rowell, L. B. (1993). Human Cardiovascular Control. New York: Oxford University Press. P. 1-483.

Saltin, B., Radegran, G., Koskolou, M. D., Roach, R. C. (1998). Skeletal muscle blood flow in humans and its regulation during exercise. Acta Physiologica Scandinavica, 162 (3), 421-436.

Strong, W. B., Malina, R. M., Blimkie, C. J. et al. (2005). Evidence based physical activity for school-age youth. Journal of Pediatrics, 146 (6), 732-737.

Vainoras, A. (1996). Investigation of the heart repolarization process during rest and bicycle ergometry (100lead and standard 12 - lead ECG data): Synopsis of a D. Sc. habil. thesis. Kaunas.

Vainoras, A., Poderys, J., Jasiūnas, V. (2000). Sportininku širdies ir kraujagysliu sistemos rodikliai aktyviai treniruojantis ir baigus sportinę veiklą. Lietuvos bendrosios praktikos gydytojas, T. 4, 3, 236-238.

Wilmore, J. H., Costill, D. L. (1999). Physiology of Exercise and sport. Champaign, JL. P. 549.

Winsley, R. J., Armstrong, N., Bywater, K., Fawkner, S. G. (2003). Reliability of heart rate variability measures at rest and during light exercise in children. British Journal of Sports Medicine, 37 (6), 550-552.

Žemaitytè, D. (1997). Širdies ritmo autonominis reguliavimas: mechanizmai, vertinimai, klinikiné reikšmé. Palanga.

Платонов, В. Н. (2004). Система подготовки спортсменов в олимпийском спорте. Общая теория и её практические приложения. Киев: Олимпийская литература.

\section{THE PECULIARITIES OF 11-14 YEARS OLD BOYS' MUSCLES AND CARDIOVASCULAR SYSTEMS EFFECT OF REGULAR LONG-TERM SPORTS GAMES AND CYCLICAL SPORTS EVENTS EXERCISES}

\author{
Arūnas Emeljanovas, Eurelija Venskaitytė, Laura Danusevičiūtė, Jonas Poderys \\ Lithuanian Academy of Physical Education, Kaunas, Lithuania
}

\begin{abstract}
The aim of this study was to determine the effect of regular long term sports games and cyclical sports events exercises on 11-14 years old boys' muscles and cardiovascular systems adaptation peculiarities. For this purpose we estimated the development of muscles system and alteration of cardiovascular system
\end{abstract}


indices in non-athletes boys and boys who trained in sports games and cyclical sports events. The specialized computer program "Kaunas-Load" was employed for electrocardiogram (ECG) recording and analysis on purpose to assess the changes of the functional state and adaptation peculiarities in 11-14 years old boys. Also participants of this study underwent $30 \mathrm{~s}$ duration vertical jump test to evaluate the relative muscles' capability. For that purpose a contact platform connected to computer program was used, which computes vertical jump height and relative take-off capability.

The results of muscles working capacity obtained during the study confirmed the opinion of other authors that regular exercises have positive influence on 11-14 year-old boys' jump height and 11-13 year-old boys' dynamics of relative muscles'capability per $30 \mathrm{~s}$ as the worst indices were assessed in non-athletes group. The evaluation of cardiovascular system indices showed that better results were rather characteristic for boys who trained in sports games than others. The heart rate of sports games group was lower than cyclical sports events group and non-athletes (especially it was distinguished at the age of 13 years), that indicates better sports games group exercise-induced adaptation. Also 13 years old sports games group electrocardiogram's JT interval values after workload were significantly $(\mathrm{p}<0.05)$ better than in cyclical sports events and in non-athletes' groups. Such results can be explained as the optimal physical loads for the children of the given age are those, which have more influence on the development of muscles peculiarities and rather lesser degree - on cardiovascular system.

In summarizing we conclude, that the interaction of external and internal factors determines the development of 11-14 year-old boys' muscles and cardiovascular system functional capability. Moreover, the study results allow to maintain that sports games training is a significant external factor, which influences faster alteration of cardiovascular system indices at the age of 13 years, but at the age of 14 years endogenous factors have the most influence on it.

Keywords: adaptation, aging, cardiovascular system.

Gauta 2006 m. gegužès 25 d.

Received on May 25, 2006

Priimta $2006 \mathrm{~m}$. rugsèjo $12 \mathrm{~d}$.

Accepted on September 12, 2006

\author{
Arūnas Emeljanovas \\ Lietuvos kūno kultūros akademija \\ (Lithuanian Academy of Physical Education) \\ Sporto g. 6, LT-44221 Kaunas \\ Lietuva (Lithuania) \\ Tel +370 37302650 \\ E-mail a.emeljanovas@1kka.1t
}

